\title{
Space structure and diversity of island vegetation on Torey lakes in drought period in Daursky reserve
}

\author{
Lyudmila Saraeva* \\ Daursky State Nature Biosphere Reserve, Nizhniy Tsasuchey, 76 Komsomolskaya Str., Zabaikalsky \\ krai, Russia
}

\begin{abstract}
The Torey lakes of Daursky reserve belong to wetlands of international importance and are located in the south of Zabaikalsky krai. In 2009, in the drought period, we studied the space structure and diversity of the vegetation on five islands in the Torey lakes. The results of ecological-phytocenotic classification are presented. 52 associations related to 15 formations and 4 types of island vegetation on the Torey lakes are identified.
\end{abstract}

\section{Introduction}

The Daursky nature reserve with the area of 49,764 ha, and the buffer zone of 173,201 ha is located in the south of Transbaikal territory at the border with Mongolia. The reserve includes the Torey lakes inscribed in the list of wetlands of international importance under Ramsar convention. The Torey lakes consist of soda lakes Barun-Torey and Zun-Torey. The Torey lakes are at the intersection of two powerful bird flyways - the EastasianAustralasian and Eastasian-Indian ones. Barun-Torey Lake feeds the steppe Ulda and Imalka rivers. Zun-Torey Lake feeds atmospheric precipitation and the groundwater to the surface. In the aquatorium of Torey lakes there are eleven islands of different area (Fig. 1). The islands serve as a nesting site for colonial semiaquatic birds including rare ones, such as Relict gull (Larus relictus). The islands of Torey section are one of the world's four nesting sites of Relict gull.

The reserve is situated in the zone of extremely continental climate. The peculiar feature of the climate is great amplitude of fluctuations in 24-hour and year temperatures, and uneven distribution of seasonal and many-year precipitation. 24-hour fluctuations of temperature reach $15-20^{\circ} \mathrm{C}$, and year ones $-80^{\circ} \mathrm{C}$. During dry years $150 \mathrm{~mm}$ precipitation fall, in wet years - up to $350 \mathrm{~mm}$. Cyclic changes in humidity with alternation of drought and wet periods about 30 years in duration are characteristic of Dauria [1]. The Torey lakes have a changeable hydrological pattern. On the map charts based on the deciphering of space shots changes in the area of the water surface of the Torey lakes are observed (Fig.2). In the wet period in 2000 the area of the Torey lakes water surface was $852 \mathrm{~km}^{2}$, in $2005-750 \mathrm{~km}^{2}$, in $2007-650 \mathrm{~km}^{2}$, in $2008-550 \mathrm{~km}^{2}$, in 2009 г. $-285 \mathrm{~km}^{2}$. The year 2009 was the most

\footnotetext{
* Corresponding author: bagul72@mail.ru
} 
droughty. In May 2009 Lake Barun-Torey dried up. Lake Zun-Torey got considerably low and the island Aral of the Zun-Torey joined the shore.

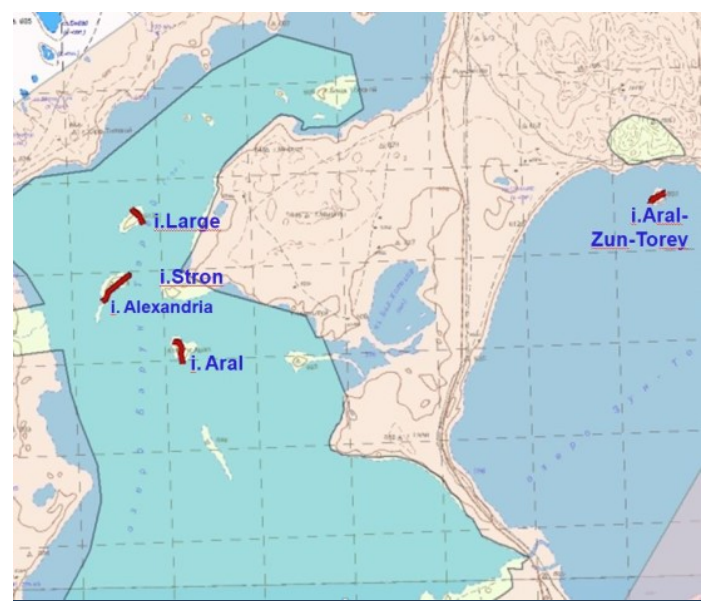

Fig. 1. Location of studied islands on Torey lakes

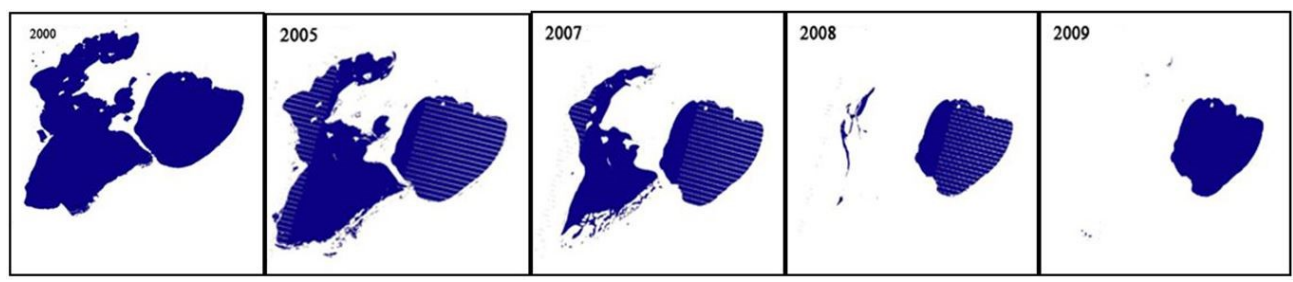

Fig. 2. Monitoring of the area of Torey lakes water surface in 2000-2009 rivers Uldza, Imalka that fill the Torey lakes dried up. A lot of small steppe lakes in the Torey hollow ran dry.

\section{Materials and methods}

In 2009 we studied five islands: Alexandria $\left(\right.$ area $\left.-11 \mathrm{~km}^{2}\right)$, Aral $\left(8.5 \mathrm{~km}^{2}\right)$, Bolshoy $(8.7$ $\left.\mathrm{km}^{2}\right)$, Kamenny $\left(0.6 \mathrm{~km}^{2}\right)$ and Aral of the Zun-Torey $\left(5.1 \mathrm{~km}^{2}\right)$. On each island we laid a geobotanical profile. Geobotanical descriptions of the vegetation were conducted according to the standard methodology [2]. This paper is based on the material from 78 geobotanical descriptions of the islands vegetation. Classification of the island vegetation on the Torey lakes was done on the ecologo-phytocenotic principles laid out by E.M. Lavrenko [3]. To associations we ascribe communities with a unified composition of edificators and coedificators, homogeneous synusial structure. Formations are identified by the basic edificator and are joined into groups.

\section{Results and discussion}

The purpose of the study is describing the space structure and diversity of the vegetation on five islands of the Torey lakes in the droughty period.

We considered a typical example of the distribution of island vegetation belts on the geobotanical profile of the Bolshoy island (Fig. 3). The profile has a total length of $1 \mathrm{~km}$ $140 \mathrm{~m}$, is oriented from the south-east to north-west and laid across the top of the island (with a height of $609 \mathrm{~m}$ above sea level).The spatial distribution of vegetation is shown in Fig. 3 at the level of ecological-phytocenotic classification formations, the description is 
made at the level of associations. The main influence on the distribution of vegetation has a position of associations in the relief. The relief is generally flat-flat, from the top to the coastal shaft, gently sloping (angle of inclination up to 3 degrees) slopes descend.

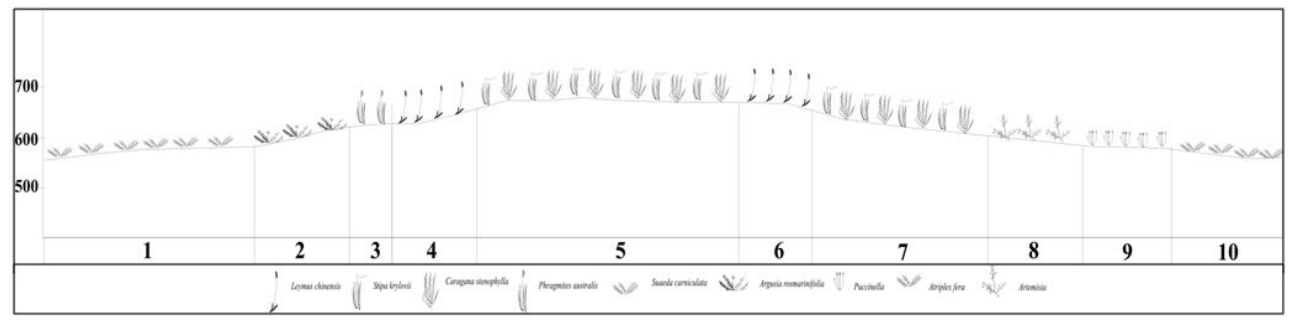

Fig. 3. Vegetation of Bolshoy island. Formations: 1, 10. Seepweed; 2. Saltmarsh-grass; 3, 9. Argusia; 4. Reed; 5, 7. Leymus; 6, 8 Stipa

On the shores and smooth slopes of the island Bolshoy we distinguish three meadow formations - Argusia, Saltmarsh-grass and Seepweed ones. The Seepweed formation (1, 10) comprises seepweed (Suaeda corniculata) and Suaeda corniculata - Knorringia sibirica associations. The coastal areas of the island, recently freed from the water, are captured by the pioneer halophytic associations from Suaeda corniculata. Puccinellia formation (2) is represented by the association of the same name, in which the main dominants are Puccinellia tenuiflora and P. macranthera. The Argusia formation $(3,9)$ includes association Argusia rosmarinifolia - Puccinellia tenuiflora. The upper convex part of the island is occupied by steppe vegetation of Leymus and Stipa formations. The Leymus formation $(5,7)$ includes association Leymus chinensis - Allium polyrhizum; the Stipa formation $(6,8)$ - association Stipa krylovii - Caragana stenophylla. The reed formation (4), described by us in the middle part of the southeastern slope, consists of hydrophyte monodominant species Phragmites australis thickets. Reed thickets in the dry period occupy small areas.

The islands of the Torey Lakes are natural refugiums for rare species and associations. Five rare species have been found on the islands: Asparagus brachyphyllus, a species listed in the Red Book of the Russian Federation [4] and Ephedra dahurica, Limonium aureum, Nitraria sibirica, Astragalus miniatus, species included in the Red Book of the Transbaikal territory [5]. Of the rare and endemic associations, the following were described: Oxytropis prostrata - Suaeda corniculata, Oxytropis prostrata - Melilotus suaveolens - Argusia rosmarinifolia with the participation of the endemic species Oxytropis prostrata; and Argusia rosmarinifolia - Convolvulus ammanii, Argusia rosmarinifolia - Puccinellia macranthera - Knorringia sibirica, Artemisia anethifolia - Nitraria sibirica, Argusia rosmarinifolia - Puccinellia macranthera - Puccinellia tenuiflora, with Argusia rosmarinifolia xerophilous tertiary desert-steppe Central Asian relict.

A change of vegetation from halophytic to steppe communities is characteristic of almost all studied islands. An exception is island Kamenny, which has small area $-0.6 \mathrm{~km}^{2}$. In the vegetation of the island, of pioneer seepweed, seepweed-orach, orach associations with participation of annual and biennial halophytic species Atriplex fera and Suaeda corniculata are described. Steppe vegetation is not developed due to the small area of the island. Hydrophytic vegetation is represented by the Reed formation. Thickets of reeds are noted for the Aral, Alexandria and Bolshoy Islands. In the dry season, reed areas degrade and shrink. Below is the ecologo-phytocenotic classification of the island vegetation of the Torey lakes (Table). 
Table. Ecologo-phytocenotic classification of the island vegetation of the Torey lakes

\begin{tabular}{|c|c|c|}
\hline $\begin{array}{l}\text { Vegetation } \\
\text { type }\end{array}$ & $\begin{array}{l}\text { Name of } \\
\text { formation }\end{array}$ & Name of association \\
\hline \multirow[t]{23}{*}{ Steppes } & Onion & $\begin{array}{c}\text { Sage-onion (Allium polyrhizum-Artemisia gmelinii - Artemisia } \\
\text { frigida) }\end{array}$ \\
\hline & & Sage-onion (Allium polyrhizum - Artemisia anethifolia) \\
\hline & Sage & Onion-sage (Artemisia commutata - Allium polyrhizum) \\
\hline & & $\begin{array}{c}\text { Onion-sage (Artemisia frigida - Artemisia gmelinii - Allium } \\
\text { polyrhizum) }\end{array}$ \\
\hline & & $\begin{array}{c}\text { Caragana-sage (Artemisia scoparia - Artemisia gmelinii-Caragana } \\
\text { stenophylla) }\end{array}$ \\
\hline & Wild rye & $\begin{array}{c}\text { Sage-onion-wild rye (Leymus chinensis - Allium polyrhizum- } \\
\text { Artemisia scoparia) }\end{array}$ \\
\hline & & Stipa-wild rye (Leymus chinensis - Stipa krylovii) \\
\hline & & Sage-wild rye (Leymus chinensis - Artemisia frigida) \\
\hline & & $\begin{array}{c}\text { Caragana-stipa-wild rye (Leymus chinensis - Stipa krylovii- } \\
\text { Caragana stenophylla) }\end{array}$ \\
\hline & & $\begin{array}{c}\text { Sage-stipa-wild rye (Leymus chinensis - Stipa krylovii - Artemisia } \\
\text { gmelinii) }\end{array}$ \\
\hline & & $\begin{array}{l}\text { Sage-wild rye (Leymus chinensis - Artemisia gmelinii - Artemisia } \\
\text { scoparia) }\end{array}$ \\
\hline & & $\begin{array}{c}\text { Onion-sage-wild rye (Leymus chinensis - Artemisia gmelinii- } \\
\text { Artemisia frigida - Allium polyrhizum) }\end{array}$ \\
\hline & Stipa & $\begin{array}{c}\text { Onion-stipa ( Stipa krylovii-Allium tenuissimum - Allium } \\
\text { polyrhizum) }\end{array}$ \\
\hline & & $\begin{array}{c}\text { Sage-caragana-stipa (Stipa krylovii-Caragana stenophylla- } \\
\text { Artemisia scoparia) }\end{array}$ \\
\hline & & Wild rye-stipa (Stipa krylovii - Leymus chinensis) \\
\hline & & Sage-stipa (Stipa krylovii-Artemisia scoparia) \\
\hline & & $\begin{array}{c}\text { Herbs-stipa (Stipa krylovii-Heteropapus altaicus - Allium } \\
\text { polyrhizum) }\end{array}$ \\
\hline & Stipa - shrub & Caragana-stipa (Stipa krylovii - Caragana stenophylla) \\
\hline & & $\begin{array}{c}\text { Sage-caragana-stipa ( Stipa krylovii-Caragana stenophylla- } \\
\text { Artemisia scoparia) }\end{array}$ \\
\hline & & $\begin{array}{c}\text { Caragana-onion-stipa (Stipa krylovii - Allium polyrhizum - } \\
\text { Caragana stenophylla) }\end{array}$ \\
\hline & & $\begin{array}{c}\text { Nitraria-caragana-sage-stipa steppe (Stipa krylovii - Artemisia } \\
\text { scoparia + Caragana stenophylla - Nitraria sibirica) }\end{array}$ \\
\hline & & $\begin{array}{c}\text { Caragana-sage-stipa ( Stipa krylovii - Artemisia scoparia + } \\
\text { Caragana stenophylla) }\end{array}$ \\
\hline & $\begin{array}{l}\text { Forbred- } \\
\text { leymus- } \\
\text { shrubby }\end{array}$ & $\begin{array}{c}\text { Caragana-nitraria-herbs-wild rye (Leymus chinensis - Thermopsis } \\
\text { lanceolata - Saussurea amara }+ \text { Nitraria sibirica - Caragana } \\
\text { stenophylla) }\end{array}$ \\
\hline \multirow[t]{5}{*}{$\begin{array}{c}\text { Halophytic } \\
\text { meadows }\end{array}$} & Saltmarsh-grass & $\begin{array}{c}\text { Argusia-nitraria-saltmarsh-grass (Puccinellia macranthera - Nitraria } \\
\text { sibirica - Argusia rosmarinifolia) }\end{array}$ \\
\hline & & $\begin{array}{c}\text { Argusia-saltmarsh-grass (Puccinellia macranthera - Argusia } \\
\text { rosmarinifolia) }\end{array}$ \\
\hline & & $\begin{array}{l}\text { Knorringia-saltmarsh-grass (Puccinellia macranthera - Knorringia } \\
\text { sibirica) }\end{array}$ \\
\hline & & Saltmarsh-grass (Puccinellia tenuiflora - Puccinellia macranthera) \\
\hline & & $\begin{array}{c}\text { Nitraria-saltmarsh-grass (Puccinellia macranthera - Nitraria } \\
\text { sibirica) }\end{array}$ \\
\hline \multirow{2}{*}{$\begin{array}{l}\text { Complex } \\
\text { pioneer and }\end{array}$} & Seepweed & Orach-seepweed (Suaeda corniculata - Atriplex fera) \\
\hline & & Seepweed (Suaeda prostrata - Suaeda corniculata) \\
\hline
\end{tabular}




\begin{tabular}{|c|c|c|}
\hline $\begin{array}{l}\text { Vegetation } \\
\text { type }\end{array}$ & $\begin{array}{l}\text { Name of } \\
\text { formation }\end{array}$ & Name of association \\
\hline \multirow[t]{21}{*}{$\begin{array}{l}\text { halophytic } \\
\text { vegetation }\end{array}$} & & $\begin{array}{l}\text { Argusia-knorringia-seepweed ( Suaeda corniculata - Knorringia } \\
\text { sibirica - Argusia rosmarinifolia) }\end{array}$ \\
\hline & & $\begin{array}{c}\text { Knorringia-argusia-seepweed ( Suaeda prostrata - Argusia } \\
\text { rosmarinifolia - Knorringia sibirica) }\end{array}$ \\
\hline & & $\begin{array}{c}\text { Saltmarsh-grass-seepweed ( Suaeda prostrata - Puccinella } \\
\text { macranthera) }\end{array}$ \\
\hline & & Pigweed-seepweed ( Suaeda corniculata - Atriplex fera) \\
\hline & & Knorringia-seepweed ( Suaeda corniculata - Knorringia sibirica) \\
\hline & & $\begin{array}{l}\text { Argusia-saltmarsh-grass-seepweed ( Suaeda corniculata - } \\
\text { Puccinellia macranthera - Argusia rosmarinifolia) }\end{array}$ \\
\hline & & $\begin{array}{l}\text { Argusia-seepweed ( Suaeda prostrata - Argusia } \\
\text { rosmarinifolia) }\end{array}$ \\
\hline & Kochia & $\begin{array}{l}\text { Seepweed-kochia (Kochia densiflora- Suaeda } \\
\text { corniculata) }\end{array}$ \\
\hline & & $\begin{array}{l}\text { Sage-seepweed-kochia ( Kochia densiflora - Suaeda } \\
\text { corniculata - Artemisia comutata) }\end{array}$ \\
\hline & Argusia & Bindweed-argusia (Argusia rosmarinifolia - Convolvulus ammanii) \\
\hline & & $\begin{array}{c}\text { Saltmarsh-grass-argusia ( Argusia rosmarinifolia - Puccinellia } \\
\text { macranthera - Puccinellia tenuiflora) }\end{array}$ \\
\hline & & $\begin{array}{c}\text { Knorringia-saltmarsh-grass-argusia ( Argusia rosmarinifolia - } \\
\text { Puccinellia macranthera - Knorringia sibirica) }\end{array}$ \\
\hline & & Pigweed-argusia (Argusia rosmarinifolia - Atriplex fera) \\
\hline & Orach & Seepweed-orach (Atriplex fera - Suaeda corniculata) \\
\hline & & Argusia-orach (Atriplex fera - Argusia rosmarinifolia) \\
\hline & & Orach (Atriplex fera) \\
\hline & Oxytrope & Seepweed-oxytrope (Oxytropis prostrata - Suaeda corniculata) \\
\hline & & $\begin{array}{c}\text { Argusia-melilot-oxytrope ( Oxytropis prostrata - Melilotus } \\
\text { suaveolens - Argusia rosmarinifolia) }\end{array}$ \\
\hline & Melilot & Argusia-melilot (Melilotus suaveolens - Argusia rosmarinifolia) \\
\hline & & $\begin{array}{c}\text { Knorringia-argusia-melilot (Melilotus suaveolens - Argusia } \\
\text { rosmarinifolia - Knorringia sibirica) }\end{array}$ \\
\hline & Sagebrush & Nitraria-sagebrush (Artemisia anethifolia - Nitraria sibirica) \\
\hline $\begin{array}{l}\text { Hydrophytic } \\
\text { vegetation }\end{array}$ & Reed & Reed (Phragmites australis) \\
\hline
\end{tabular}

Thus, the analysis of the spatial structure of vegetation showed that the change of plant associations and formations is closely related to the position in the relief: the areas with similar relief have similar vegetation that varies from halophytic to steppe associations. Such a structure of vegetation is characteristic of the large islands of Alexandria, Bolshoi, Aral and Aral-Zun-Torey. As a rule, pioneer and halophytic vegetation grows along the coast and in the coastal zone of the islands. On the gentle slopes of the islands, it is replaced by halophytic saltmarsh-grass meadows, with spots of hydrophytic reed vegetation. On convex summit relief forms, halophytic vegetation is replaced by steppe vegetation. During the dry period, an increase in the area of pioneer halophytic vegetation and a decrease in hydrophytic vegetation were observed on the islands. The diversity of island vegetation of the Torey Lakes is represented by 52 associations belonging to 16 formations and 4 types of vegetation. The islands of the Torey Lakes are natural refugiums for rare species and endemic associations.

\section{References}


1. V. Kirilyuk, T. Tkachuk, O. Kirilyuk, Problems of adaptation to climate change in Dauria river basins: ecological and hydroeconomic aspects, 5 (2012)

2. Field geobotany, 3 (L., 1964)

3. E.M. Lavrentyev, Vegetation of USSR, 2 (M, 1940)

4. The Red Book of the Russian Federation (plants and fungi) (M, KMK, 2008)

5. Red Book of the Trans-Baikal Territory. Plants (Novosibirsk, House of peace, 2017) 